MINI RISET

\title{
RETRIBUSI PARKIR TEMPAT WISATA DI DAERAH BOYOLANGU
}

\author{
Siti Nur Nafi'ah (stnurnafik28@gmail.com) \\ Anas Nur Azizah (anasnurazizah08@gmail.com) \\ Aaisy Intan Nabiilah (aisyntn@gmail.com)
}

Universitas Tulungagung

\begin{abstract}
ABSTRAKSI
Pemerintah daerah dalam bidang perpajakan memungut pajak daerah sebagai sumber penerimaan daerah untuk mendukung pelaksanaan otonomi daerah dan membiayai penyelenggaraan pemerintah. Pajak parkir merupakan jenis pajak yang dipungut sebagai sumber penerimaan daerah. Tujuan penelitian untuk mengetahui bagaimana tingkat efektivitas dan besarnya potensi pajak parkir tempat wisata di daerah boyolangu. Penelitian dilakukan di Nangkula Park, Njegong Park, Agro Wisata Blimbing, Tegal Pule dan Kampung Wisata Hidroponik Sobontoro di daerah boyolangu. Metode penelitian deskriptif kuantitatif, yaitu menganalisis data dan menghitung besarnya potensi dari tahun ketahun selanjutnya beserta tingkat efektivitas pemungutannya. Hasil penelitian menunjukkan setiap tahun perolehan potensi pajak parkir dapat meningkat dilihat dari peningkatan pembangunan tempat wisata tersebut. Penelitian ini bertujuan untuk mengetahui system pemungutan retribusi parkir tempat wisata di daerah Boyolangu, mengidentifikasi permasalahan yang terjadi dalam pelaksanaannya, serta untuk mengetahui kontribusi retribusi parkir terhadap PAD Kota Tulungagung. Teknik pengambilan sumber data yang digunakan dalam penelitian ini adalah metode wawancara dan survey secara langsung. Hasil penelitian menunjukkan bahwa system pemungutan retribusi parkir ini yang kisaran nominalnya tidak selalu sama antara pemungutan parkir tempat wisata dengan tempat wisata lainnya.
\end{abstract}

Kata kunci : Retribusi parkir, tempat wisata. Pemungutan parkir.

\begin{abstract}
Local governments in the field of taxation collect local taxes as a source of regional revenue to support the implementation of regional autonomy and finance government administration. Parking tax is a type of tax collected as a source of regional revenue. The purpose of the study was to find out how the level of effectiveness and the amount of potential parking tax for tourist attractions in the Boyolangu area. The research was conducted in Nangkula Park, Njegong Park, Blimbing agro tourism, Tegal Pule and Sobontoro hydroponic tourism village in the Boyolangu area. Descriptive quantitative research method, namely analyzing the data and calculating the amount of potential from year to year along with the level of effectiveness of the collection. The results of the study show that every year the potential for parking taxes can increase, seen from the increase in the construction of these tourist attractions. This study aims to determine the parking levy collection system for tourist attractions in the Boyolangu area,
\end{abstract}


identify problems that occur in its implementation, and to determine the contribution of parking fees to PAD in Tulungagung City. The data source collection technique used in this research is the direct interview and survey method. The results of the study indicate that this parking levy collection system whose nominal range is not always the same between parking collections for tourist attractions and other tourist attractions.

Keywords: Parking retribution, tourist attractions. Parking colaction.

\section{PENDAHULUAN}

Pajak merupakan salah satu penerimaan Negara. Membayar pajak oleh warga negara merupakan kewajiban dan penerimaan dari pajak ini sangat penting bagi pemerintah dalam rangka membelanjai kegiatan pemerintah dan pembangunan serta pelayanan publik. Seiring dengan itu, peranan pajak dalam hal pendanaan juga akan semakin besar. Oleh sebab itu diperlukan usaha untuk meningkatkan pendapatan pemerintah yang berasal dari pajak. (Rachmad Gesah Mukti Prabowo, SE. Ak, 2014) Negara Republik Indonesia adalah negara hukum berdasarkan Undang-Undang Dasar 1945 yang menjunjung tinggi hak dan kewajiban setiap masyarakat. Negara Indonesia menempatkan perpajakan sebagai peran serta kewajiban kenegaraan dalam rangka kegotongroyongan nasional sebagai peran serta aktif masyarakat dalam membiayai pembangunan. Otonomi Daerah telah memberikan keleluasaan Pemerintah Daerah untuk menjalankan Konstitusi sebagai ujung tombak pembangunan ekonomi daerah untuk kepentigan rakyat. Salah isu utama yang menjadi agenda reformasi adalah adanya perubahan sistem pemerintahan daerah dari sentralistik menuju ke dentralistik. Pemberian otonomi luas kepada daerah ditujukan untuk mempercepat terwujudnya kesejahteraan masyarakat melalui peningkatan pelayanan, pemberdayaan, dan peran serta masyarakat.

Retribusi atau jasa yang disediakan atau diberikan oleh pemerintah daerah untuk tujuan kepentingan dan kemanfaatan umum serta dapat dinikmati oleh orang pribadi atau badan. Retribusi parkir masuk dalam retribusi jasa umum karena memberikan manfaat khusus bagi orang pribadi atau badan yang diharuskan membayar retribusi, disamping untuk melayani kepentingan dan kemanfaatan umum. Di tempat wisata daerah Boyolangu masuk dalam retribusi jasa umum karena di tempat wisata tersebut menyediakan sarana dan tempat hiburan bagi wisatawan dalam atau luar daerah.

Potensi yang bisa diambil oleh pemerintah daerah seperti Kabupaten Tulungagung adalah potensi dari sektor pajak. Pajak menjadi salah satu kewajiban yang dibayarkan oleh masyarakat yang dampaknya berpengaruh pada pendapatan daerah. Semakin tinggi pendapatan 
yang diperoleh dari sektor pajak maka beban anggaran akan semakin kecil. Dana bagi hasil pajak dan bukan pajak antara pemerintah daerah dan pemerintah pusat menjadi saran untuk dapat meningkatkan perekonomian daaerah melalui pengeluaran yang bersifat wajib. Selain itu Kabupaten Tulungagung mengguanakan Retribusi Daerah sebagai sumber pemasukan anggaran yang cukup efektif. Retribusi Daerah yang terdiri dari retribusi jasa umum antara lain pelayanan keamanan dan pelayanan kebersihan, jasa pengelolaan tempat wisata dan retribusi perijinan tertentu merupakan sektor yang sangat besar untuk digali dan diperluas pengelolaannya.

Tulungagung memiliki 19 Kecamatan salah satunya di kecamatan boyolangu, di kecamatan tersebut memiliki beberapa tempat wisata yang dapat dikunjungi antara lain : Nangkula Park, Njegong Park, Agro Wisata Blimbing, Tegal Pule dan Kampung Wisata Hidroponik. Terdapat struktur atau bagian yang paling berpengaruh dan berhubungan dengan konsep penataannya. Bagian pendukung merupakan bagian yang harus disediakan daalm mendukung aktivitas di dalam parkir tempat wisarta. Terdapat komponen tersebut meliputi: Lahan yang di tempati, Jalan utama, Identitas (papan nama, gapura atau tugu), Papan informasi, Toilet, Mushola, Air bersih, Parkir, Pemadam kebakaran, Tempat pembuangan sampah,, Karcis, pagar tempat parkir.

Dengan meningkatnya jumlah kendaraan bermotor setiap tahunnya, maka bertambah pula pendapatan retribusi parkir di tempat wisata. Khususnya di Daerah Boyolangu. Pungutan pajak mengurangi penghasilan atau kekayaan individu tetapi sebaliknya merupakan penghasilan masyarakat yang kemudian di kembalikan lagi kepada masyarakat, melaui pengeluaran-pengeluaran rutin dan pengeluaran pembangunan yang akhirnya kembali lagi kepada seluruh masyarakat yang bermanfaat bagi rakyat, baik yang membayar maupun tidak. Pajak mempunyai peran yang sangat penting bagi kehidupan bernegara, khususnya didalam pembangunan karena pajak merupakan sumber penghasilan negara untuk membiayai semua pengeluaran, termasuk pengeluaran pembangunan khusunya tempat wisata tersebut.

Penelitian ini bertujuan untuk melihat bagaimana kondisi di lapangan terkait dengan retribusi parkir di tempat wisata. Dari latar belakang di atas maka perumusan masalah dalam mini riset ini adalah apakah dari beberapa sampel pemungutan parkir tempat wisata di daerah Boyolangu kabupaten Tulungagung melakukan pembayaran Retribusi parkir atau tidak. 


\section{LANDASAN TEORI}

\section{Pengertian pajak}

Menurut Soemitro dalam (Rachmad Gesah Mukti Prabowo, SE. Ak, 2014) pajak adalah iuran rakyat kepada kas negara berdasarkan Undang-undang (yang dapat dipaksakan) dengan tidak mendapatkan jasa timbal (kontraprestasi), yang langsung dapat ditunjukkan dan yang digunakan untuk membayar pengeluaran umum.

Menurut Mardiasmo dalam (Rachmad Gesah Mukti Prabowo, SE. Ak, 2014) pengertian pajak adalah Iuran rakyat kepada kas negara berdasarkan undang-undang (yang dapat dipaksakan) dengan tiada mendapatkan imbalan jasa (kontra prestasi) yang langsung dapat ditunjukkan dan yang digunakan untuk membayar pengeluaran umum. Pungutan pajak yang dilakukan pemerintah tujuannya adalah untuk memenuhi kebutuhan keuangan pemerintah untuk belanja negara agar penyelenggaraan pemerintahan tetap berjalan.

\section{Fungsi Pajak}

Mardiasmo dalam (Malombeke, 2016) mengatakan terdapat dua fungsi pajak, yaitu fungsi budgetair (sumber keuangan negara) dan fungsi regularend (pengatur).

1. Fungsi Budgetair

2. Fungsi Regularend

\section{Syarat Pemungutan Pajak}

Mardiasmo dalam (Malombeke, 2016) menyatakan bahwa syarat pemungutan pajak harus memenuhi syarat sebagai berikut:

a. Pemungutan pajak harus adil (Syarat Keadilan)

b. Tidak menggangu perekonomian (Syarat Ekonomis)

c. Pemungutan pajak harus efisien (Syarat Finansiil)

d. System pemungutan pajak harus sederhana.

\section{Teori-Teori yang mendukung pemungutan pajak}

Mardiasmo dalam (Malombeke, 2016) menyatakan bahwa teori-teori tersebut antara lain sebagai berikut:
a. Teori Asuransi
b. Teori Kepentingan 

c. Teori Daya Pikul
d. Teori Bakti
e. Teori Asas Daya Beli

\section{Tarif Pajak}

Mardiasmo dalam (Malombeke, 2016) menyatakan bahwa ada empat tarif pajak yaitu sebagai berikut :
a. Tarif sebanding/proposional
b. Tarif tetap
c. Tarif Progresif

\section{Pengertian Retribusi}

Retribusi adalah pungutan daerah sebagai pembayaran atas jasa atau pemberian izin tertentu yang khusus disediakan dan atau diberikan oleh pemerintah daerah untuk kepentingan orang pribadi atau badan. Dalam arti lain, retribusi adalah pembayaran wajib dari penduduk kepada Negara karena adanya jasa tertentu yang diberikan oleh Negara bagi penduduknya secara perorangan. Jasa tersebut dapat dikatakan bersifat langsung, yaitu hanya yang membayar retribusi yang menikmati balas jasa dari Negara.

Retribusi Daerah adalah pungutan sebagai pembayaran atas jasa yang disediakan oleh Pemerintah Daerah. Berbeda dengan pajak daerah adalah iuran wajib yang dilakukan oleh daerah kepada orang pribadi atau badan tanpa imbalan langsung yang seimbang, yang dapat dipaksakan berdasarkan peraturan perundang- undang yang berlaku, yang digunakan untuk membiayai penyelenggaraan pemerintah daerah dan pembangunan daerah. Dengan demikian, pajak daerah merupakan pajak yang ditetapkan oleh pemerintah daerah dengan peraturan daerah (Perda), yang wewenang pemungutannya dilakukan oleh pemerintah daerah dan hasilnya digunakan untuk membiayai pengeluaran pemerintah daerah dalam melaksanakan penyelenggarakan pemerintah dan pembangunan di daerah.

Unsur yang melekat pada pengertian retribusi adalah sebagai berikut:

1) Pungutan retribusi harus berdasarkan undang-undang

2) Sifat pungutannya dapat di paksakan

3) Pemungutannya dilakukan oleh Negara

4) Digunakan untuk pengeluaran bagi masyarakat umum 
5) Imbalan langsung dapat diserahkan oleh pembayar retribusi. (Nahar, 2014)

\section{Jenis-Jenis Retribusi Daerah}

Dibawah ini penjelasan retribusi beserta jenis-jenisnya adalah, sebagai berikut:

1.) Retribusi jasa umum

Retribusi jasa umum adalah retribusi atas jasa yang disediakan atau diberikan oleh pemerintah daerah, untuk tujuan, kepentingan dan kemanfaatan umum sertas dapat dinikmati oleh orang pribadi atau badan.

Retribusi jasa umum, diantaranya adalah sebagai berikut:

a) Retribusi pelayanan kesehatan

b) Retribusi pelayanan persampahan atau kebersihan

c) Retribusi pergantian biaya cetak Kartu Tanda Penduduk dan Akta Catatan Sipil

d) Retribusi pelayanan pemakaman dan pengabuan mayat

e) Retribusi parkir di tepi jalan umu

f) Retribusi pasar

g) Retribusi air bersih

h) Retribusi pengujian kendaraan bermotor

i) Retribusi pemeriksaan alat pemadam kebakaran

j) Retribusi pergantian cetak peta

k) Retribusi pengujian kapal perikanan

2.) Retribusi jasa usaha

Retribusi jasa usaha adalah retribusi atas jasa yang disediakan oleh pemerintah daerah dengan menganut prinsip komersial karena pada dasarnya dapat pula disediakan oleh sektor swasta.

Retribusi jasa usaha, diantaranya adalah sebagai berikut:

a) Retribusi pemakaian kekayaan daerah

b) Retribusi pasar grosir dan atau pertokoan

c) Retribusi tempat pelelangan

d) Retribusi terminal

e) Retribusi tempat khusus parkir

f) Retribusi tempat penginapan atau pesanggahan atau villa

g) Retribusi penyedotan kakus

h) Retribusi rumah potong hewan 
i) Retribusi pelayanan pelabuhan kapal

j) Retribusi tempat rekreasi dan olahraga

k) Retribusi penyeberangan di atas air

1) Retribusi pengelolaan limbah cair

m) Retribusi penjualan produksi usaha daerah.

3.) Retribusi perizinan tertentu

Retribusi perizinan tertentu adalah retribusi atas kegiatan tertentu pemerintah daerah dalam rangka pemberian izin kepada orang pribadi atan badan yang dimaksudkan untuk pembinaan, pengaturan, pengendalian dan pengawasan atas kegiatan pemanfaatan ruang, penggunaan sumber daya alam, barang, prasarana, sarana, atau fasilitas tertentu guna melindungi kepentingan umum dan menjaga kelestarian lingkungan.

Retribusi perizinan tertentu, adalah sebagai berikut:

a) Retribusi izin mendirikan bangunan

b) Retribusi izin tempat penjualan minuman baralkohol

c) Retribusi izin gangguan

d) Retribusi izin trayak.

\section{Pendapatan Asli Daerah (PAD)}

Pendapatan asli daerah (PAD) merupakan salah satu komponen sumber pendapatan daerah sebagaimana telah diatur dalam Undang-undang Nomor 33 Tahun 2004 tentang Perimbangan Keuangan Antara Pusat dan Daerah Pasal 1 angka 18 menyatakan bahwa Pendapatan asli daerah, selanjutnya disebut PAD adalah pendapatan yang diperoleh daerah yang dipungut berdasarkan peraturan daerah sesuai dengan peraturan perundang-undangan.

\section{Sumber-Sumber Pendapatan Asli Daerah}

UU No. 32 Tahun 2004 Tentang Pemerintahan Daerah dan UU No. 33 Tahun 2004 Tentang Perimbangan Keuangan antara Pemerintah Pusat dan Pemerintahan Daerah, sumber Pendapatan Asli Daerah terdiri atas:

1. Hasil Pajak Daerah

2. Hasil Retribusi Daerah

3. Hasil Pengelolaan Kekayaan Daerah Yang Dipisahkan 


\section{Pajak Daerah}

Mardiasmo dalam (Malombeke, 2016) menyatakan sesuai dengan Undang-Undang No. 28 Tahun 2009 tentang Pajak Daerah dan Retribusi Daerah mengemukakan beberapa istilah yang terkait dengan Pajak Daerah, sebagai berikut:
a. Daerah Otonom
b. Pajak Daerah
c. Badan
d. Subjek Pajak
e. Wajib Pajak

\section{Ciri-Ciri Pajak Daerah}

Ciri-ciri pajak daerah menurut Siahaan dalam (Malombeke, 2016) adalah sebagai berikut :

a. Pajak dipungut oleh Negara

b. Pembayaran pajak harus masuk kepada kas Negara

c. Dalam pembayaran pajak tidak dapat ditunjukkan adanya kontra prestasi individu oleh pemerintah (tidak ada imbalan langsung yang diperoleh pembayar pajak).

d. Penyelenggaraan pemerintahan secara umum merupakan manifestasi kontra prestasi dari Negara kepada para pembayar pajak.

e. Pajak dipungut karena adanya suatu keadaan, kejadian, dan perbuatan yang menurut peraturan perundang- undangan pajak dikenakan pajak.

f. Pajak memiliki sifat dapat dipaksakan.

\section{Jenis dan Tarif Pajak}

Jenis dan tarif pajak daerah yang dapat dipunggut oleh pemerintah daerah di atur dalam UU No. 28 Tahun 2009, menurut Syukriy Abdullah yaitu adalah sebagai berikut:

a. Jenis dan Tarif Pajak Propinsi adalah sebagai berikut:

1. Pajak Kendaraan Bermotor dan Kendaraan di Atas Air $10 \%$

2. Bea Balik Nama Kendaraan Bermotor dan Kendaraan di Atas Air 20

3. Pajak Bahan Bakar Kendaraan Bermotor 10\%

4. Pengambilan dan Pemanfaatan Air Bawah Tanah dan Air Permukaan 30\%.

5. Pajak Pengambilan Bahan Galian Golongan C $25 \%$

6. Pajak Parkir $30 \%$ 
b. Jenis dan Tarif Pajak Kabupaten atau Kota adalah sebagai berikut:

1. Pajak Kendaraan Bermotor $30 \%$

2. Pajak Bahan Bakar Kendaraan Bermotor $70 \%$

3. Pajak Air Permukaan 50\%

4. Pajak Rokok $70 \%$

5. Pajak Penerangan Jalan $10 \%$

\section{Pajak Parkir}

Menurut Siahaan dalam (Malombeke, 2016) mengemukakan bahwa berdasarkan Pasal 1 Undang-Undang No. 28 Tahun 2009 tentang Pajak Daerah dan Retribusi Daerah, Pajak Parkir adalah pajak atas penyelenggaraan tempat parkir di luar badan jalan, baik yang disediakan berkaitan dengan pokok usaha maupun yang disediakan sebagai suatu usaha, termasuk penyediaan tempat penitipan kendaraan bermotor.

\section{Dasar Hukum Pemungutan Pajak Parkir}

Dasar hukum pemungutan pajak parkir menurut Siahaan dalam (Malombeke, 2016) adalah sebagai berikut:

a. Undang-Undang Nomor 28 Tahun 2009 tentang Pajak Daerah dan Retribusi Daerah.

b. Undang-Undang Nomor 34 Tahun 2000 yang merupakan perubahan atas UndangUndang Nomor 18 Tahun 1997 tentang Pajak Daerah dan Retribusi Daerah.

c. Peraturan Pemerintah Nomor 65 Tahun 2001 tentang Pajak Daerah.

d. Peraturan Daerah Kota Manado Nomor 2 Tahun 2011 tentang Pajak Daerah.

e. Peraturan Daerah Kota Manado Nomor 2 Tahun 2011 Bagian Ketujuh Pasal 39-44 tentang Pajak Parkir.

\section{Peraturan Bupati Tulungagung No. 33 Tahun 2003 Tentang Petunjuk Pelaksanaan} Peraturan Daerah Kabupaten Tulungagung No 10 Tahun 2011 Tentang Penyelenggaran Perparkiran Di Kabupaten Tulungagung.

\section{Tata Cara Pemungutan Retribusi Parkir}

Pasal 4

(1) Tata cara pemungutan retribusi parkir di tepi jalan umum, sebagai berikut :

a. Kendaraan yang masuk ke daerah parkir ditata dengan bantuan juru parkir; 
b. Kendaraan yang akan meninggalkan daerah parkir diberikan tanda pembayaran retribusi parkir di tepi jalan umum berupa karcis parkir;

c. Tanda pembayaran retribusi parkir di tepi jalan umum sebagaimana dimaksud pada huruf b diberikan kepada kendaraan dari luar wilayah Daerah;

(2) Tata cara pemungutan retribusi parkir berlangganan, sebagai berikut :

a. Membayar pajak tahunan kendaraan bermotor di Badan yang telah ditentukan;

b. Pembayaran pajak sebagaimana dimaksud pada huruf a sudah terdapat pembayaran retribusi parkir berlangganan;

c. Bagi yang lunas membayar retribusi parkir berlangganan, sslqgai tanda bukti diberikan tanda parkir berlangganan (stiker) oleh petugas dan ditempelkan pada kendaraan;

d. Warna tanda parkir berlangganan (stiker) setiap tahunnya berbeda.

(3) Bentuk, wama dan ukuran tanda pembayaran retribusi parkir di tepi jalan umum dan tanda parkir berlangganan (stiker) sebagaimana dimaksud pada ayat (1) huruf $b$ dan ayat (2) huruf c, tercantum dalam Lampiran II peraturan Bupati ini.

\section{Ketentuan Retribusi}

Pasal 5

(1) Bagi orang atau Badan yang memarkir kendaraannya atau menggunakan tempat khusus parkir yang telah ditentukan diwajibkan membayar retribusi parkir;

(2) Bagi pemilik kendaraan dengan Nomor polisi dari luar wilayah Daerah tapi setiap hari beroperasi di Daerah, dapat pula menjadi pelanggan parkir;

(3) Pemungutan retribusi parkir di tepi jaran umum dilakukan oleh petugas/iuru parkir dengan tanda bukti berupa karcis;

(4) Pemungutan retribusi parkir berlangganan dilakukan bersamaan dengan pembayaran pajak kendaraan bermotor setiap tahun dengan tanda bukti berupa stiker;

(5) Hasil dari pemungutan retribusi parkb disetor secara bruto ke Kas Daerah.(Peraturan, 2013)

\section{Objek dan Subjek Pajak Parkir}

Objek Pajak Parkir menurut Siahaan dalam (Malombeke, 2016) adalah penyelenggaraan tempat Parkir di luarbadan jalan, baik yang disediakan berkaitan dengan pokok usaha maupun yang disediakan sebagai suatu usaha, termasuk penyediaan tempat penitipan kendaraan bermotor. Tidak termasuk objek pajak adalah: 
a. Penyelenggaraan tempat Parkir oleh Pemerintah dan Pemerintah Daerah.

b. Penyelenggaraan tempat Parkir oleh perkantoran yang hanya digunakan untuk karyawannya sendiri.

c. Penyelenggaraan tempat Parkir oleh kedutaan, konsulat, dan perwakilan negara asing dengan asas timbal balik.

d. Penyelenggaraan tempat Parkir lainnya yang diatur dengan Peraturan Daerah.

\section{Dasar Pengenaan, Tarif, dan Cara Perhitungan Pajak Parkir}

Dasar pengenaan, tarif dan cara perhitungan pajak parkir menurut Siahaan dalam (Malombeke, 2016) adalah sebagai berikut.

a. Dasar Pengenaan Pajak Parkir

b. Tarif Pajak Parkir

c. Perhitungan Pajak Parkir

d. Secara umum Perhitungan Pajak Parkir adalah sesuai dengan rumus sebagai berikut :

\section{Pajak Terutang $=$ Tarif Pajak $\mathbf{x}$ Dasar Pengenaan Pajak $=$ Tarif Pajak x Jumlah Pembayaran atau yang Seharusnya dibayar kepada penyelenggara tempat parkir}

\section{Potensi}

Dalam Kamus Umum bahasa Indonesia, kata "potensi" mempunyai arti suatu kemampuan yang masih bisa dikembangkan lebih lanjut. Sedangkan Hamroli Harun mendefinisikan potensi sebagai suatu „,kemampuan ekonomi yang ada didaerah yang mungkin dan layak untuk dikembangkan sehingga bisa berkembang menjadi sumber penghidupan rakyat setempat bahkan dapat mendorong perekonomian daerah secara keseluruhan untuk berkembang dengan sendirinyadan berkesinambungan. 


\section{METODE PENELITIAN}

Sugiyono dalam (Malombeke, 2016) Penelitian ini termasuk pada jenis penelitian deskriptif. Mendefinisikan bahwa Penelitian deskriptif yaitu penelitian yang berusaha untuk menuturkan pemecahan masalah yang ada sekarang berdasarkan data-data. Jenis penelitian deskriptif kualitatif yang digunakan pada penelitian ini dimaksudkan untuk menganalisis dan memperoleh gambaran tentang Potensi Retribusi Pajak parkir tempat wisat Terhadap Peningkatan Pendapatan Asli Daerah (PAD) daerah kecamatan Boyolangu, Kabupaten Tulungagung. Mini riset ini dilakasanakan pada bulan Mei 2021 di Nangkula Park, Njegong Park, Agro Wisata Blimbing, Tegal Pule dan Kampung Wisata Hidroponik Sobontoro yang beralamat di desa, kecamatan boyolangu, Kabupaten Tulungagung. Penelitian tentang Potensi Retribusi Pajak parkir Terhadap Peningkatan Pendapatan Asli Daerah (PAD) daerah kecamatan Boyolangu, kabupaten Tulungagung, dilakukan di berbagai tempat antara lain: Nangkula Park, Njegong Park, Agro Wisata Blimbing, Tegal Pule dan Kampung Wisata Hidroponik.

\section{Jenis dan sumber data}

Jenis penelitian ini adalah jenis penelitian kualitatif dan tipe penelitian adalah tipe penelitian deskriptif yang menghasilkan gambaran akurat tentang sebuah kelompok, menggambarkan mekanisme sebuah proses, memberikan gambaran lengkap baik dalam bentuk verbal maupun numerikal, serta menyajikan informasi dasar akan suatu hubungan. Sumber data yang digunakan dalam penelitian yakni data primer dan data sekunder. Dalam penelitian ini, pengumpulan data dilakukan melalui beberapa teknik yakni wawancara, observasi.

1. Jenis Data

Menurut Narbuko dalam (Handayani, 2017), Adapun jenis data yang digunakan dalam penelitian ini adalah sebagai berikut :

a. Data Primer adalah data yang diperoleh dari objek penelitian lapangan dengan cara mengumpulkan data-data yang berguna dan berhubungan dengan judul dan permasalahan yang diangkat.

b. Data Sekunder adalah data yang diperoleh dari keterangan atau fakta-fakta yang ada dan secara tidak langsung melalui bahan-bahan dokumen berupa peraturan perundangundangan, buku kepustakaan dan sebagainya.

2. Sumber Data Sumber data yang digunakan peneliti dalam penelitian ini antara lain : 
a. Sumber Data Primer adalah sumber data yang diperoleh secara langsung dari lapangan yang meliputi keterangan atau data yang diberikan oleh pedangan yang berjualan di pasar tersebut. Hasil Wawancara dari beberapa sampel tempat wisata di daerah Boyolangu.

b. Sumber Data Sekunder adalah sumber data yang secara langsung mendukung sumber data primer yang mencakup dokumen-dokumen resmi, buku-buku, hasil-hasil penelitian yang serupa dengan penelitian ini.

\section{Teknik Pengumpulan Data}

Adapun teknik pengumpulan data yang akan digunakan dalam penelitian ini yaitu teknik observasi, wawancara, kuesioner,dan dokumentasi.

1. Observasi, dilaksanakan untuk keperluan pengumpulan data dengan cara mengamati dan mencatat secara sistematis mengenai aktivitas ditempat wisata.

2. Wawancara mendalam, yaitu peneliti mengajukan pertanyaan langsung kepada subjek penelitian untuk memperoleh informasi seacara rinci dan mendalam sesuai dengan permasalahan yang diteliti.

3. Dokumentasi, yaitu pengumpulan data yang sudah ada, data yang dimaksud berupa gambaran data hasil penerimaan retribusi.

4. Kuesioner/angket, adalah suatau alat pengumpulan data yang berupa serangkaian pertanyaan tertulis yang dapat diajukan kepada subyek untuk mendapatkan jawaban secara tertulis.

\section{HASIL DAN PEMBAHASAN}

Retribusi Daerah dalam bentuk Retribusi parkir termasuk dalam jenis retribusi Jasa Umum yang dipungut oleh Pemerintah Daerah kepada orang pribadi/ badan yang memakai jasa layanan perparkiran., dimana Kecamatan Boyolangu diberikan kewenangan khusus untuk memungut dan mengelola retribusi parkir tempat wisata di Kecamatan Boyolangu selalu berupaya meningkatkan pelaksanaan pengelolaan yang optimal dalam rangka meningkatkan pembangunan ekonomi. Tempat wisata yang ada didaerah Boyolangu, merupakan salah satu tempat wisata yang paling diminati oleh masyarakat sekitar dan dimana para kolektor/ petugas pemungut retribusi parkir tempat wisata tersebut melaksanakan tugasnya yaitu memungut retribusi, pengawas di tempat pemungutan retribusi ini tim pengawas atau koordinator bidang melakukan pengawasan secara langsung. 
Pengelola tempat wisata didaerah Boyolangu telah mempercantik sarana dan prasarananya, sehingga terlihat lebih indah, bersih, dan nyaman untuk dikunjungi. Wisata di daerah Boyolangu seperti Nangkula Park, Njegong Park, Agro Wisata Blimbing, Tegal Pule dan Kampung Wisata Hidroponik memang menawarkan banyak sarana untuk banyak aktifitas yaitu aktifitas ekonomi, hiburan dan wisata. Tempat wisata didaerah Boyolangu memiliki fitur unik dan menarik. Salah satu di Nangkula Park keunikannya adalah terdapat patung yang berbentuk keris. Pengunjung dapat menikmati menu yang sudah tersedia di tempat makan yang disediakan, tidak hanya di Nangkula Park tetapi di Tegal Pule juga terdapat oleh - oleh khas Tulungagung yaitu Jenang, wajik, madumangsa Pak Lasimun.

Retribusi parkir merupakan salah satu pendapatan asli daerah yang diharapkan bisa menjadi sumber pembiayaan yang digunakan untuk pembangunan daerah untuk kesejahteraan masyarakat. Suatu daerah diberi peluang dalam menggali potensi sumber-sumber keuangannya dengan menetapkan jenis retribusinya. Berdasarkan hasil penelitian yang telah dilakukan pelaksanaan pemungutan retribusi. Retribusi Parkir tempat wisata di daerah Boyolangu dilakukan secara harian sesuai dengan keteraturan layanan yang disediakan. Prosedur pemungutan yang telah ditetapkan yaitu para petugas menarik retribusi kepada pengguna lahan parkir didaerah wisata Boyolangu terutama di Nangkula Park, Njegong Park, Agro Wisata Blimbing, Tegal Pule dan Kampung Wisata Hidroponik yang kemudian dari petugas pemungutan diserahkan kepada pengelolah Retribusi Parkir tempat wisata didaerah Boyolangu.

Pemungutan retribusi ini dilakukan dengan menerapkan pemberian tiket parkir sebagai tanda bukti pembayaran, misalnya adalah pembelian tiket parkir, dimana pengunjung bisa memasuki area tempat wisata apabila sudah membayar dan memiliki tanda bukti pembayaran tiket parkir. Sejalan dengan penelitian yang dilakukan peneliti terkait masalah pengelolaan retribusi parkir tempat wisata yang dikelolah oleh kecamatan Boyolangu Kabupaten Tulungagung. Pengelolaan atau yang sering disebut manajemen merupakan suatu proses, yang diartikan sebagai usaha yang sistematis untuk menjalankan suatu pekerjaan untuk mencapai tujuan. Prinsip-prinsip dalam penerapan retribusi harus diperhatikan agar retribusi dapat mencapai tujuannya untuk membiayai pelayanan yang dilaksanakan oleh pemerintah daerah. Empat prinsip umum yang digunakan sebagai indikator dalam pengenaan retribusi menurut Davey (1988) dalam (Usman et al., 2016). yaitu sebagai berikut : kecukupan, keadilan, kemudahan administrasi dan kesepakatan politik yang dilakukan untuk menentukan dan mencapai tujuan tertentu dengan cara menggunakan manusia dan sumber-sumber lain. 
Demikian pula pada pengelolaan retribusi parkir di Nangkula Park, Njegong Park, Agro Wisata Blimbing, Tegal Pule dan Kampung Wisata Hidroponik Kota Tulungagung yang dikelola oleh Kecamatan Boyolangu yang senantiasa menerapkan fungsi-fungsi manajemen dalam pengelolaannya agar dalam pelaksanaannya senantiasa merujuk pada upaya pencapaian tujuannya. Dalam pengelolaan retribusi parkir di tempat wisata daerah Boyolangu masih menemui beberapa kendala dalam pelaksanaan pemungutan retribusi parkir. Seperti wisata njegong park untuk saat ini termasuk tempat wisata yang sedang berkembang, Hal ini terlihat dari pembangunan dan berkaikan terus berjalan serta penambahan ruas-ruas jalan untuk mempelancar transportasi sehingga pemanfaatan badan jalan digunakan pemerintah untuk memungut retribusi parkir, seperti yang terjadi di sepanjang jalan njegong park, serta jalanjalan protokol lainnya yang ada di tempat wisata daerah Boyolangu.

Dalam penataan ruang parkir perlu nantinya diperhatikan beberapa hal sebagai tolak ukur kecukupan terhadap ruang parkir. Kriteria-kriteria yang digunakan dalam penentuan kecukupan ruang parkir antara lain tempat, garasi parkir, peralatan parkir, volume parkir dan kebutuhan letak parkir. Kecukupan lahan parkir merupakan hal yang sepele tetapi memiliki dampak cukup besar jika penataannya kurang diperhatikan. Karena jika ruang parkir yang disediakan tidak mencukupi, maka parkir akan meluap di badan jalan sehingga akan mengganggu kelancaran arus transportasi. Kendaraan tidak mungkin bergerak terus menerus, pada saatnya harus berhenti sementara atau berhenti lama (parkir), yaitu keadaan tidak bergerak suatu kendaraan yang tidak bersifat sementara. Fasilitas parkir harus tersedia ditempat tujuan apabila tidak tersedia maka ruang jalan akan menjadi tempat parkir. Perparkiran telah menimbulkan persoalan dibanyak kota besar karena keterbatasan ruang kota. Ketiadaan dan ketidak cukupan fasilitas parkir dikawasan tertentu dalam kota, menyebabkan jalan menjadi tempat parkir.

Hal ini sering terjadi di salah satu tempat wisata Boyolangu yaitu Nangkula park karena salah satu tempat wisata yang paling banyak diminati oleh masyarakat Boyolangu dan tempat ini memiliki keistimewaan tersendiri bagi peminatnya apalagi dihari libur akan menimbulkan macet berkepanjangan karena ruas jalan di sepanjang nangkula park dijadikan lahan perparkiran oleh pihak pihak yang tidak bertanggu jawab.

Aktivitas suatu pusat kegiatan akan menimbulkan aktivitas parkir kendaraan. Hal ini akan menimbulkan masalah antara lain :

1. Permintaan parkir tidak dapat tertampung oleh fasilitas parkir yang tersedia sehingga meluap kebadan jalan. Luapan parkir di badan jalan akan mengakibatkan gangguan kelancaran arus lalu lintas. 
2. Tidak tersedianya fasilitas parkir di luar badan jalan sehingga bangkitan parkir secara otomatis memanfaatkan badan jalan untuk parkir.

perparkiran berkaitan erat dengan kecukupan ruang, sedangkan sediaan ruang - terutama di Nangkula park sangat terbatas bergantung pada luas tempat. Bila ruang parkir dibutuhkan maka sediaan lahan merupakan masalah yang sulit, kecuali dengan mengubah sebagian peruntukannya. Jumlah kendaraan yang bertambah setiap tahun- terutama jenis kendaraan pribadi- jelas menjadi penyebab utama meningkatnya kebutuhan akan ruang parkir.

Dalam melihat sejauh mana keadilan retribusi parkir tempat wisata di daerah Boyolangu adalah pembahasan mengenai penetapan tarif yang menjadi dasar pengenaan retribusi. Ada beberapa hal yang dicermati terkait penetapan tarif antara lain sejauh mana tarif dipahami dan dimengerti oleh masyarakat, sejauh mana tarif yang ditetapkan terhadap kualitas layanan yang diberikan, keadilan dari pengenaan tarif, dan juga kaitan antara tarif yang diberikan terhadap lingkungan. Pengenaan tarif yang dilakukan oleh pemerintah daerah Boyolangu terhadap retribusi parkir ditempat wisata Boyolangu dapat dikatakan sebagai tarif yang murah, pengenaan tarif yang murah tersebut ditujukan untuk sebagai pengadaan pelayanan oleh masyarakat.

Dalam berlaku adil dalam pengenaan tarif yang rendah memang suatu hal yang baik, namun dilain pihak ada hal lain yang perlu diperhatikan yaitu mengenai kualitas layanan yang diberikan oleh pengelola serta tukang parkir sebagai pelaksana lapangan. Salah satu persoalan yang dihadapi pengguna parkir tempat wisata Boyolangu adalah terjadinya kenaikan harga tarif parkir yang tidak sesuai ketentuan yang beraku. Masalah tersebut bukanlah hal yang bisa dianggap sepele karena selain menyangkut keadilan bagi masayarakat penguna lahan parkir tempat wisata Boyolangu. Tarif retribusi parkir di tempat wisata daerah Boyolangu yang murah memiliki keunggulan dimana tarif tersebut diterima secara luas oleh masyarakat dan juga memenuhi keadilan bagi seluruh lapisan, namun dilain pihak juga memiliki kendalanya, selain tadanya kenaikan tak terduga oleng orang orang yang tak bertanggu jawab juga tidak dapat memberikan pelayanan yang optimal, maka dari itu dibutuhkan tarif yang ideal untuk retribusi parkir ditempat wisata daerah Boyolangu agar dan bertanngung jawab. Tak dapat dipungkiri bahwa pengawasan memegang peranan penting sebagai upaya dalam meminimalisir masalahmasalah dalam pemungutan retribusi. Pengawasan merupakan proses pemantauan yang dilakukan sebagai langkah untuk mengetahui apakah kegiatan pelaksanaan di lapangan sudah sesuai dengan ketentuan. Dengan pengawasan yang baik maka masalah-masalah yang dapat mengurangi keberhasilan pemungutan retribusi parkir bisa diminimalisir. 
Demikian halnya dalam pemungutan retribusi parkir di tempat wisata daerah Boyolangu yang dilakukan untuk menghindari, menekan seminimal mungkin terjadinya kesalahan yang mungkin saja terjadi. Apabila dalam pengelolaan retribusi parkir di tempat wisata daerah Boyolangu tanpa dilakukan pengawasan, maka akan mengalami kesulitan dalam mengukur tingkat keberhasilan yang dilaksanakan oleh para petugas yang melaksanakan pemungutan retribusi parkir di tempat wisata daerah Boyolangu. Dengan pengawasan yang baik maka kecendrungan akan timbulnya kesalahan yang kurang mendukung keberhasilan dalam pemungutan retribusi parkir dapat ditekan seminimal mungkin.

Pengawasan dalam hal ini dilakukan oleh pengelolah retribusi parkir tempat wisata didaerah Boyolangu yang langsung mengadakan peninjauan dan pemeriksaan atas pelaksanaan kegiatan di lapangan yang berhubungan dengan pemungutan retribusi parkir dan peninjauan letak parkir yang sesuai dengan aturan dan tidak melewati batas. Kordinator lapangan sebagai penanggung jawab pengawasan penagihan retribusi parkir setiap 3 kali dalam seminggu turun ke lapangan mengawasi para personilnya dalam melaksanakan pemungutan retribusi parkir untuk menghindari terjadinya penyimpangan, penyelewengan, hambatan, kesalahan dan sebagainya yang dapat menghambat pencapaian penerimaan retribusi parkir tempat wisata didaerah Boyolangu. Selain itu kordinator lapangan juga melakukan pengawasan terhadap letak titik parkir yang tidak melampui batas dan jika melampui batas dapat menggangu kelancaran lalu lintas disekitarnya.

Pada umumnya digunakan sebagai ukuran keberhasilan perangkat usaha dan kegiatan dalam rangka pencapaian sasaran yang telah ditetapkan. Efektifitas penerimaan retribusi dalam hal ini merupakan gambaran kemampuan dari unit organisasi pengelola retribusi untuk mencapai sasaran yang telah ditetapkan. kegiatan penarikan retribusi ini terlihat mudah dan tidak sulit untuk dilakukan, namun ada saatnya kegiatan pungutan atau penerimaan retribusi menjadi lebih rumit, antara lain adalah disaat musim liburan atau ada kegiatan tertentu dimana pengunjung yang datang meningkat tajam ketimbang dengan hari biasa. Proses yang dilakukan setelah dilakukan pungutan atas retribusi parkir tempat wisata didaerah Boyolangu adalah pembukuan, dimana dalam proses ini dilakukan pencatatan atas berapa uang yang telah diterima oleh pihak pengelolah retribusi parkir tempat wisata didaerah Boyolangu.

Hal tersebut merupakan sebuah tahapan penting dalam sebuah retribusi, karena selain menerima hasil, pengelola juga harus mencatat dan untuk dilaporkan kepada pemerintah diatasnya. Pencatatan yang dilakukan merupakan gambaran secara nominal dari apa yang telah dilakukan oleh pengelola, sejauh mana hasil yang diperoleh dapat dilihat dari hasil pembukuan dan pencatatan tersebut. Pihak pengelola bertugas dalam membuat pencatatan dan pembukuan 
yang dilakukan setiap harinya, dan setelah itu diserahkan ke pengelola keuangan daerah. Dalam sistem administrasi dalam pelaporan ini juga tentunya lebih memudahkan pemerintah akan retribusi tersebut melalui laporan keuangan yang telah dilaporkan. karena dengan sistem yang ada dapat meminimalkan terjadinya kesalahan, kalaupun seandainya terjadi kesalahan dapat dilakukan rekonsiliasi melalui mencocokan antara laporan keuangan yang diterima dengan laporan yang dibuat oleh unit-unit pelaksana dibawahnya. (Usman et al., 2016)

Berikut tabel sempel tempat wisata yang ada di daerah Boyolangu yang menerapkan tiket parkir bagi wisatawan :

\begin{tabular}{|c|l|c|c|c|}
\hline \multirow{2}{*}{ No } & \multicolumn{2}{|c|}{ Tempat } & \multicolumn{3}{c|}{ Retribusi Parkir } \\
\cline { 3 - 5 } & \multicolumn{1}{|c|}{ Motor } & Mobil & Bus \\
\hline 1 & Nangkula Park & 3.000 & 5.000 & 10.000 \\
\hline 2 & Njegong Park & 3.000 & 5.000 & 10.000 \\
\hline 3 & Tegal Pule & 2.000 & 5.000 & 10.000 \\
\hline 4 & Kampung Wisata Hidroponik & 2.000 & 5.000 & 10.000 \\
\hline 5 & Agro Wisata Blimbing & 3.000 & 5.000 & 10.000 \\
\hline
\end{tabular}




\section{KESIMPULAN}

Berdasarkan hasil penelitian yang telah dilakukan, maka penulis dapat menarik beberapa kesimpulan sebagai berikut:

1. Karena wisatawan merupakan orang yang sedang berlibur atau pelancong yang menikmati segala hal yang ada didaerah tujuan wisata atau tempat wisata tersebut dan menikmati pelayanan yang ada ditempat wisata tersebut maka wisatawan disebut sebagai subjek retribusi.

2. Besarnya pemungutan parkir di tentukan dengan jenis kendaraan yang di pakai seperti Motor sebasar Rp 2000 sampai Rp 3000, Mobil sebesar Rp 5000, dan Bis sebesar 10.000 pada tempat parkir wisata di Daerah Boyolangu.

3. Karena dalam hal ini bukan saja untuk tempat wisata, tetapi sebagai upaya untuk memperkenalkan desa Boyolangu kemasyarakat yang luas. selain dengan semakin banyak yang mengenal desa Boyolangu, perekonomian dapat meningkat terutama masyarakat yang tinggal diarea tempat wisata.

4. Pola pemungutan retribusi parkir di tempat wisata dapat dilihat dari penentuan objek parkir dan besarnya setoran retribusi tiap objek ditetapkan melalui survei oleh dinas terkait pada tempat-tempat yang dinilai memiliki potensi parkir, dengan melihat frekuensi pemanfaatan pelayanan parkir.

\section{SARAN}

1. Dinas Perhubungan, Komunikasi dan Informatika dalam menentukan objek parkir hendaknya tidak hanya melihat sisi ekonomi suatu objek, akan tetapi objek tersebut juga harus menunjang kenyamanan dan kelancaran lalu lintas di suatu Kawasan tempat wisata. Hal ini bisa dicapai dengan pemasangan rambu-rambu parkir pada setiap objek parkir yang ditentukan.

2. Pemerintah Kota Tulungagung perlu meningkatkan sosialisasi baik dengan masyarakat sebagai (pengguna parkir) maupun para juru parkir terkait implementasi kebijakan retribusi parkir, sehingga masyarakat menyadari akan pentingnya penerimaan retrbusi parkir dalam memberikan kontribusi terhadap PAD dan pembangunan.

3. Pelaksanaan pemungutan retribusi parkir, dibutuhkan suatu sistem pengawasan (controlling) yang baik antar instansi terkait (implementator) dengan para juru parkir (jukir) agar mereka bekerja secara efektif dan bertanggungjawab, dengan demikian kecenderungan akan kemungkinan timbulnya kebocoran-kebocoran dalam pemungutan retribusi parkir akan dapat ditekan seminimal mungkin. 


\section{DAFTAR PUSTAKA}

Handayani, S. (2017). Potensi Retribusi Pasar Terhadap Peningkatan Pendapatan Asli Daerah (Pad) Kabupaten Lamongan. Jurnal Akuntansi, 2(1), 24. https://doi.org/10.30736/jpensi.v2i1.96

Malombeke, N. (2016). ANALISIS POTENSI DAN EFEKTIVITAS PEMUNGUTAN PAJAK PARKIR DI KABUPATEN MINAHASA UTARA. Jurnal Riset Ekonomi, Manajemen, Bisnis Dan Akuntansi, 4(1). https://doi.org/10.35794/emba.v4i1.11767

Nahar, K. (2014). PEMBAHASAN UMUM TENTANG RETRIBUSI, IJARAH (SEWAMENYEWA) DAN KHARAJ. In Skripsi (pp. 17-46).

Peraturan, P. (2013). PERATURAN BUPATI TULUNGAGUNG NOMOR 33 TAHUN 2013. 4, $1-18$.

Rachmad Gesah Mukti Prabowo, SE. Ak, M. (2014). Analisis Pemenuhan Pembayaran Pajak Bumi Dan Bangunan Untuk Meningkatkan Penerimaan Sektor Pajak. 1(1), 103-120.

Usman, J., Mappamiring, \& Parawangi, A. (2016). PENGELOLAAN SERTA KEBIJAKAN RETRIBUSI PARKIR PANTAI LOSARI MAKASSAR. Jurnal Administrasi Publik, 2(1), 32-47. 